Jurnal Riset Agama

Volume 1, Nomor 1 (April 2021): 15-28

https://journal.uinsgd.ac.id/index.php/jra

\title{
Hadis tentang Haid dan Pengaruh Alat Kontrasepsi Pencegah Kehamilan terhadap Siklus Haid
}

\author{
Annisaa Siti Zuadah \\ Department of Hadith Science, Faculty of Usuluddin \\ UIN Sunan Gunung Djati Bandung \\ annisaasitizuadah@gmail.com
}

\begin{abstract}
This study aims to discuss the hadith about menstruation. This research method is a qualitative type through literature study with content analysis. The research discussion includes general views about menstruation, hadith about menstruation, and the effect of contraceptives to prevent pregnancy on the menstrual cycle. This study concludes that menstruation is a natural cycle as a stipulation that has been established for women based on the explanation of the Prophet's hadith, thereby dismissing various discriminatory myths against menstruating women. Indeed, the menstrual cycle is messed up with the use of contraceptives to prevent pregnancy, but the medical world explains that blood that comes out of the end of a woman's uterus due to the use of contraception that exceeds its period is still categorized as menstruation.
\end{abstract}

Keywords: Contraception, Hadith, Medical, Menstruation

\begin{abstract}
Abstrak
Penelitian ini bertujuan untuk membahas hadis tentang haid. Metode penelitian ini merupakan jenis kualitatif melalui studi pustaka dengan analisis isi. Pembahasan penelitian meliputi pandangan umum tentang haid, hadis tentang haid, dan pengaruh alat kontrasepsi pencegah kehamilan terhadap siklus haid. Penelitian ini menyimpulkan bahwa haid merupakan siklus alamiah sebagai ketentuan yang telah ditetapkan bagi kaum perempuan berdasarkan penjelasan hadis Nabi sehingga menepis berbagai mitos diskriminatif terhadap wanita haid. Memang siklus haid menjadi kacau dengan penggunaan kontrasepsi pencegah kehamilan, namun dunia medis menjelaskan bahwa darah yang keluar dari ujung rahim wanita karena penggunaan kontrasepsi yang melebihi masanya maka masih dikategorikan haid.
\end{abstract}


Jurnal Riset Agama, Volume 1, Nomor 1 (April 2021): 15-28

Annisaa Siti Zuadah/Hadis tentang Haid dan Pengaruh Alat Kontrasepsi

Pencegah Kehamilan terhadap Siklus Haid

Kata kunci: Alat kontrasepsi, Hadis, Haid, Medis

\section{Pendahuluan}

Telah menjadi kodrat bagi setiap wanita dewasa yang normal, bahwa mereka akan mengalami siklus bulanan kewanitaan yang dikenal dengan haid (menstruasi). Haid adalah masalah lazim yang wajib diketahui oleh setiap muslimah sebagai siklus. Namun, ada kalanya penggunaan alat kontrasepsi mengubah siklus haid mulai dari ketentuan warna, waktu, dan batasan-batasan yang rumit seperti pendarahan plasenta previa, blody slow, dan infeksi kontrasepsi yang bukan termasuk haid melainkan istihadhah. Permasalahan haid berkaitan dengan prasyarat peribadahan, seperti shalat, puasa, thowaf (umrah dan haji), pernikahan, kedewasaan, dan kesehatan. Oleh karena itu, pengetahuan tentang haid dan hal-hal yang berkaitan dengannya akibat sebab-sebab tertentu tampaknya perlu mendapat penjelasan secara memadai, terutama agar setiap ibadah yang dijalani oleh muslimah, hukumnya sah dan terhindar dari dosa (Romdion, 2015).

Sejumlah pakar telah melakukan penelitian berkenaan dengan haid sebagaimana dalam tinjauan pustaka penelitian ini. Antara lain Nasution, Nafsiyah. (2015), Judul "Studi Kualitas Sanad Hadits Membaca Al-Quran bagi Wanita Junub, Haid dan Nifas Tanpa Menyentuh Mushaf." Penerbit UIN Sultan Syarif Kasim Riau. Artikel ini menggunakan metode penelitian Takhrij al-Hadits. Hasil pembahasan artikel ini menyatakan bahwa hadis tentang membaca Al-Quran bagi wanita junub hadisnya shahih dari jalur periwayatan Ahmad bin Hambal, sedangkan hadis yang melarang wanita haid dan nifas membaca Al-Quran yang diriwayatkan iman at-Tirmidzi adalah dhaif. Artikel ini menyimpulkan bahwa bagi wanita junub haram hukumnya membaca Al-Quran, sedangkan bagi wanita yang haid dan nifas diperbolehkan membaca Al-Quran, akan tetapi lebih baik tidak membacanya sebagai bentuk kehati-hatian dalam menghormati Al-Quran (Nafsiyah, 2015). Ain, Amira. (2017), Judul: "Studi Komparatif Penganut Agama Islam Masjid Pusdai dan Penganut Agama Hindu Pura Agung Wira Loka Natha." Penerbit UIN Sunan Gunung Djati Bandung. Artikel ini menggunakan metode penelitian komparatif dengan pendekatan normatif. Hasil pembahasan artikel ini menyatakan bahwa wanita menstruasi dalam pandangan agama Islam dan Hindu sedang berada dalam keadaan kotor atau tidak suci. Artikel ini menyimpulkan bahwa wanita menstruasi dalam agama Islam dan Hindu dilarang beribadah kepada Allah Swt dan beribadah yang berkaitan dengan yajna (penyembahan kepada Tuhan) (Ain, 2017). Isna, Muhammad. (2018), Judul: "Kontekstualisasi Larangan Talak Wanita Haid." Penerbit Jurnal Studi Gender dan Islam UIN Sunan Kalijaga. Artikel ini membahas kontekstualisasi larangan talak bagi wanita haid dalam praktikum perceraian di pengadilan agama saat ini. Ditemukan 
Jurnal Riset Agama, Volume 1, Nomor 1 (April 2021): 15-28

Annisaa Siti Zuadah/Hadis tentang Haid dan Pengaruh Alat Kontrasepsi

Pencegah Kehamilan terhadap Siklus Haid

adanya illat hukum larangan talak bertujuan untuk menghindari kesewenang-wenangan seorang suami dalam menceraikan istrinya (Isna, 2018).

Berbagai penelitian terdahulu berharga dalam penyusunan kerangka berfikir penelitian ini. Haid adalah darah yang keluar dari kemaluan perempuan dalam kondisi sehat, bukan penyakit maupun akibat kehamilan (Romdion, 2015). Telah menjadi kodrat bagi setiap wanita normal, untuk mengalami siklus bulanan menstruasi (Romdion, 2015). Dalam pemahaman masyarakat Indonesia, terdapat larangan bagi wanita haid untuk tidak memotong kuku, rambut, menyisir dan keramas (Suhendra, Nilai Kearifan Lokal dalam Hadis: Studi atas Hadis Perempuan Menstruasi, 2014). Sabda Nabi Saw tentang haid tersebar dalam kutub atTis 'ah (Rahmatullah, Hadis (menstruasi) dalam tinjauan hadis, 2016). Ditinjau dari aspek Jarh wa Ta'dil, tidak ada ulama' yang menilai negatif tentang periwayatan hadis tersebut (Rahmatullah, Hadis (menstruasi) dalam tinjauan hadis, 2016). Hadis terkait dengan haid dari segi sanad dan matan adalah shahih (Rahmatullah, Hadis (menstruasi) dalam tinjauan hadis, 2016). Problem ini mengacaukan konsep fikih, tentang masa haid perempuan paling lama 15 hari bisa menjadi lebih dari 15 hari karena penggunaan alat kontrasepsi (Muttaqin K. , 2019). Dalam pandangan masyarakat, masa terpendek haid adalah 24 jam (satu malam) dan normalnya 6-7 hari dan maksimalnya 15 hari (Muttaqin K. , 2019). Dalam dunia medis waktu haid yang lebih dari 15 hari masih bisa dikategorikan sebagai haid, kecuali terjadi pendarahan plasenta previa, blody slow, dan infeksi kontrasepsi. Hal tersebut bukan termasuk haid, melainkan istihadhah (Muttaqin K. , 2019).

Berdasarkan paparan di atas, penulis berusaha menyusun formula penelitian, yaitu rumusan masalah, pertanyaan utama penelitian, dan tujuan penelitian (Darmalaksana, Metode Penelitian Kualitatif Studi Pustaka dan Studi Lapangan, 2020). Rumusan masalah penelitian ini adalah terdapat konsep haid dalam hadis. Pertanyaan utama penelitian ini adalah bagaimana konsep haid dalam hadis. Sedangkan pertanyaan secara terperinci yaitu bagaimana pandangan umum tentang haid, bagaimana hadis tentang haid, dan bagaimana pengaruh alat kontrasepsi pencegah kehamilan terhadap siklus haid. Tujuan penelitian ini yakni membahas hadis tentang haid. Penelitian ini diharapkan memiliki manfaat bagi pengayaan khazanah pengetahuan Islam.

\section{Metode Penelitian}

Metode penelitian ini merupakan jenis kualitatif melalui studi pustaka dengan analisis isi (Darmalaksana, Metode Penelitian Kualitatif Studi Pustaka dan Studi Lapangan, 2020). 
Jurnal Riset Agama, Volume 1, Nomor 1 (April 2021): 15-28

Annisaa Siti Zuadah/Hadis tentang Haid dan Pengaruh Alat Kontrasepsi

Pencegah Kehamilan terhadap Siklus Haid

\section{Hasil dan Pembahasan Penelitian}

Hasil dan pembahasan penelitian di bawah ini:

\section{Pandangan Umum tentang Haid.}

Secara etimologis haid adalah السيلا ن yang artinya sesuatu yang mengalir. Sedangkan secara teminologis, haid adalah darah yang keluar dari ujung rahim seorang wanita dalam kondisi sehat dan tidak dalam keadaan melahirkan. Darah yang keluar tersebut mempunyai kriteria umum, misalnya warna, sifat, dan batas waktu yang telah ditentukan (Nuraniyah, Fikih Menstruasi: Menghapus Mitos-Mitos dalam Menstrual Taboo, 2019). Dalam Al-Quran lafad haid disebutkan empat kali dalam dua ayat; sekali dalam bentuk fi il mudhari (yahid) dan tiga kali dalam bentuk isim masdar (al-Mahid). Menurut hukum Islam, haid adalah darah kotor yang keluar dari rahim seorang wanita sehat tanpa ada sebab dan terlaranglah baginya menjalankan ibadah (Agustina, 2019). Pada umumnya seorang wanita pertama kali mengalami haid ketika telah mencapai umur sembilan tahun, akan tetapi ada juga yang pertama kali mengalami haid lebih dari umur tersebut. Keadaan seperti ini tergantung dari kondisi fisik dan psikisnya. Sedangkan darah yang keluar sebelum umur sembilan tahun, maka hal tersebut bukanlah disebut darah haid melainkan darah istihadhah atau darah penyakit (Rochmah, 2016). Perbedaan ini disebabkan karena tidak adanya penjelasan dari nash mengenai hal tersebut. Para ulama menetapkan batasan tersebut hanya dengan melihat kebiasaan dan keadaan seorang perempuan (Agustina, 2019). Nabi Muhammad Saw pernah bersabda kepada Fatimah binti Abu Hubaisy mengenai darah haid "Sesungguhnya darah haid itu warnanya kehitam-hitaman sebagaimana yang sudah dikenal. Jika yang keluar dengan ciri-ciri itu, maka janganlah mengerjakan shalat. Namun jika yang keluar darah selain itu, maka berwudhu lalu kerjakanlah shalat. Sebab itu hanyalah darah yang keluar dari urat (karena adanya gangguan)." Sifat darah ini berwarna merah kehitaman yang kental, keluar dalam jangka waktu tertentu, dan memiliki bau khas yang tidak sedap. Tentulah seorang wanita yang telah mengalaminya, harus selalu menjaga kebersihan dan tidak melanggar syari at Islam terhadap aturan yang telah ditetapkan (Rochmah, 2016).

Ibnu Rushd memaparkan persoalan penting yang menyangkut urusan wanita, yaitu terkait haid. Darah haid termasuk salah satu tabiat wanita, sebagaimana yang disinggung oleh Aisyah ra, "Inilah perkara yang ditetapkan Allah Swt atas anak perempuan Adam." Karena memiliki rahim, seorang perempuan harus mengalami mengandung, melahirkan dan menstruasi. Kodrat tersebut telah melekat dalam diri seorang perempuan sejak lahir. Tanda awal di mana seorang gadis beranjak pada kematangan dan kedewasaan. Menurut syari at Islam darah yang keluar dari rahim perempuan pada saat tertentu dan dengan sifat-sifat tertentu pula, maka ia 
Jurnal Riset Agama, Volume 1, Nomor 1 (April 2021): 15-28

Annisaa Siti Zuadah/Hadis tentang Haid dan Pengaruh Alat Kontrasepsi

Pencegah Kehamilan terhadap Siklus Haid

sebagai tanda persiapan pembuahan antara suami dan istri untuk menunjang kelestarian jenis manusia (Misbah, 2016). Allah Swt sangat memuliakan seorang wanita. Ketika seorang wanita haid, kondisi fisik yang pada umumnya mengalami kelemahan, maka Allah Swt melepaskan kewajiban kepadanya untuk mengerjakan ibadah di antaranya: 1) Wanita haid dilarang mengerjakan shalat, baik shalat fardhu maupun shalat sunah. Hal ini dikarenakan kondisi wanita haid dalam keadaan berhadas besar; 2) Wanita haid dilarang mengerjakan puasa, baik puasa wajib maupun puasa sunah. Namun, jika shalat yang ditinggalkan tidak wajib diganti pada saat wanita tersebut telah bersih dari haid, maka puasa wajib seperti (puasa ramadhan atau nazar) tetap harus diganti pada saat wanita tersebut suci dari haid; 3) Wanita haid dilarang mengerjakan thawaf. Jika thawaf yang ditinggalkan adalah wajib haji, maka ia hanya perlu menggantinya dengan membayar dam (denda). Sedangkan thawaf sunah seperti thawaf qudum yang ditinggalkan, maka ia tidak perlu diganti dengan dam (denda) karena tidak akan menyebabkan konsekuensi apa pun; 4) Wanita haid dilarang ditalak. Seorang istri yang haid atau nifas tidak dapat menghadapi iddahnya secara wajar karena sisa masa haid atau nifas tidak disebut sebagai masa haid. Hal tersebut dapat memperpanjang masa iddah seorang istri. Di mana, masa iddah yang berlaku 3 kali haid (bagi istri yang masih haid), 3 bulan (bagi istri yang sudah menopause), 4 bulan 10 hari (bagi istri yang ditinggal mati oleh suaminya) dan sampai melahirkan (bagi istri yang sedang hamil); dan 5) Wanita haid dilarang menyentuh dan membawa AlQuran. Sesuai dengan firman Allah Swt dalam surat al-Waqi'ah ayat 79 "Siapa saja yang sedang junub atau berhadas besar tidak diperbolehkan untuk menyentuh dan membawa Al-Quran" (Azzam, 2012).

Sebelum Islam datang, orang-orang Jahiliyah dan orang-orang Yahudi tidak mau menggauli istri-istrinya yang sedang haid, tidak mau makan bersamanya, bahkan tidak mau bertempat tinggal dalam satu rumah. Wanita haid pada masa itu seolah-olah dikucilkan dari pergaulan dengan masyarakat, hingga masa berhenti haid itu tiba. Setelah Nabi Muhammad Saw berada di Madinah dengan membawa agama Islam, datanglah sahabat Ansar yang bernama Tsabit bin Addahdah dan beberapa sahabat lainnya kepada Nabi Saw untuk menanyakan tentang haid, maka dijelaskan firman Allah Swt dalam surat al-Baqarah ayat 222 tersebut oleh Nabi Muhammad Saw "Mereka bertanya kepadamu tentang (darah) haid. Katakanlah: "Dia itu adalah suatu kotoran (najis)." Oleh sebab itu, hendaklah kalian menjauhi diri dari wanita di tempat haidnya (kemaluan). Dan janganlah kalian mendekati mereka, sebelum mereka suci (dari haid). Apabila mereka telah bersuci (mandi bersih), maka campurilah mereka itu di tempat yang diperintahkan Allah kepada kalian. Sesungguhnya Allah menyukai orang-orang yang bertaubat dan menyukai orang-orang yang menyucikan diri." Rasulullah Saw dalam hadis yang terdapat dalam shahih 
Jurnal Riset Agama, Volume 1, Nomor 1 (April 2021): 15-28

Annisaa Siti Zuadah/Hadis tentang Haid dan Pengaruh Alat Kontrasepsi

Pencegah Kehamilan terhadap Siklus Haid

al-Bukhari No. 285 telah mengultimatum bahwa "Haid bukanlah penyakit dan hal yang kotor, melainkan sebuah anugerah yang diberikan Allah Swt kepada perempuan" (Suhendra, Nilai Kearifan Lokal dalam Hadis: Studi atas Hadis Perempuan Menstruasi, 2014). Pernyataan Rasulullah Saw ini sampai kepada orang-orang Yahudi, lalu mereka seperti shock mendengarkan pernyataan tersebut. Apa yang selama ini mereka anggap tabu tiba-tiba dianggap sebagai "hal yang alami" (Rochmah, 2016). Dalam Islam, tidak ditemukan adanya mitos-mitos terhadap perempuan sebagaimana berkembang dan populer di masyarakat. Al-Quran hanya menyuarakan perempuan menstruasi itu dalam keadaan tidak suci atau orang yang sedang memiliki hadas. Kategori tersebut digunakan dalam konteks ibadah, bukan digunakan untuk mendiskriminasikan salah satu jenis kelamin (Suhendra, Nilai Kearifan Lokal dalam Hadis: Studi atas Hadis Perempuan Menstruasi, 2014). Namun pada kenyataannya, pemahaman masyarakat yang berkiblat pada keyakinan nenek moyang mereka banyak yang menganggap darah menstruasi (haid) adalah kotor, najis dan mengundang malapetaka. Stigma tersebut telah melekat pada menstruasi, sehingga memunculkan mitos-mitos yang berkembang di masyarakat seperti: 1) Larangan pergi berziarah; 2) Larangan mencuci baju; 3) Larangan membakar bekas pembalut; 4) Larangan memotong kuku; 5) Larangan mencuci rambut; 6) Larangan memotong rambut; 7) dan lain-lain. Di mana, secara tidak langsung mitos-mitos yang berkembang di masyarakat tersebut berdampak terhadap pembatasan ruang gerak seorang perempuan (Ningtyas, 2020).

\section{Hadis tentang Haid}

Terdapat hadis Nabi Saw. berkenaan dengan haid pada Sahih alBukhari Nomor 285:

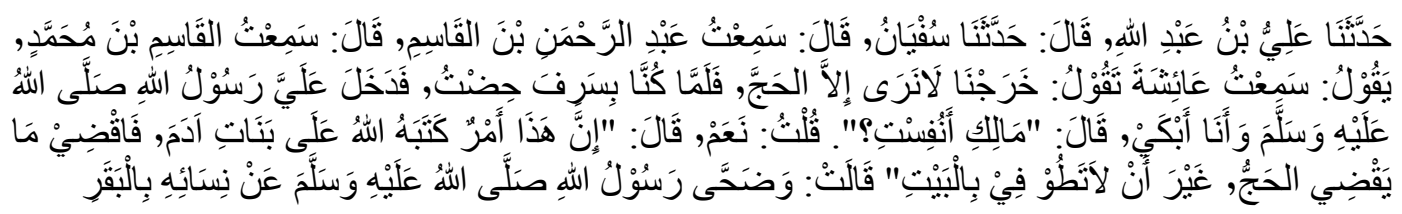

Telah meriwayatkan kepada kami 'Ali ibn 'Abd Allah, dia telah berkata: telah meriwayatkan kepada kami Sufyan, dia telah berkata: saya mendengar 'Abd ar-Rahman ibn Abu al-Qasim, dia telah berkata: saya mendengar al-Qasim ibn Muhammad berkata: saya mendengar 'Aisyah berkata, kami berangkat tanpa ada maksud selain melakukan haji. Ketika kami telah berada di suatu tempat bernama Sarif aku mengalami haid, maka Rasulullah Saw masuk menemuiku sedangkan aku dalam keadaan menangis. Beliau bertanya: Ada apa denganmu? Apakah engkau haid? Aku menjawab: Benar! Beliau bersabda: Sesungguhnya ini adalah urusan yang 
Jurnal Riset Agama, Volume 1, Nomor 1 (April 2021): 15-28

Annisaa Siti Zuadah/Hadis tentang Haid dan Pengaruh Alat Kontrasepsi

Pencegah Kehamilan terhadap Siklus Haid

telah dituliskan (ditetapkan) oleh Allah Swt terhadap perempuanperempuan keturunan Adam. Kerjakanlah apa yang biasa dikerjakan oleh orang yang menunaikan haji, hanya saja janganlah engkau thawaf di Baitullah (Ka`bah). 'Aisyah berkata: Rasulullah berkurban satu ekor sapi untuk istri-istrinya (HR. al-Bukhari: 285).

Mula-mula dilakukan pencarian melalui aplikasi hadis dengan kata kunci "Haid" hingga ditemukan hadis pada kitab Sahih al-Bukhari Nomor 285, sebagaimana dikemukakan terdahulu.

Tabel 1. Daftar Rawi Sanad

\begin{tabular}{|c|c|c|c|c|c|c|c|}
\hline \multirow[t]{2}{*}{ No } & \multirow{2}{*}{$\begin{array}{l}\text { Rawi } \\
\text { Sanad }\end{array}$} & \multicolumn{2}{|c|}{$\begin{array}{l}\text { Lahir/ } \\
\text { Wafat }\end{array}$} & \multirow{2}{*}{ Negeri } & \multirow{2}{*}{ Kuniyah } & $\begin{array}{l}\text { Komentar } \\
\text { Ulama }\end{array}$ & \multirow[t]{2}{*}{ Kalangan } \\
\hline & & $\mathrm{L}$ & W & & & + & \\
\hline 1 & `Aisyah & $\begin{array}{l}609 \\
M\end{array}$ & $\begin{array}{l}678 \\
\mathrm{M} / \\
58 \\
\mathrm{H}\end{array}$ & $\begin{array}{l}\text { Madina } \\
\mathrm{h}\end{array}$ & $\begin{array}{l}\text { Ummu } \\
\text { Abdullah }\end{array}$ & Sahabat & Sahabat \\
\hline 3 & $\begin{array}{l}\text { al-Qasim } \\
\text { ibn } \\
\text { Muham } \\
\text { mad bin } \\
\text { Abi } \\
\text { Bakar } \\
\text { Ash- } \\
\text { Shidiq }\end{array}$ & $\begin{array}{l}655 \\
M\end{array}$ & $\begin{array}{l}724 \\
\mathrm{M} / \\
106 \\
\mathrm{H}\end{array}$ & $\begin{array}{l}\text { Madina } \\
\mathrm{h}\end{array}$ & $\begin{array}{l}\text { Abu } \\
\text { Muham } \\
\text { mad }\end{array}$ & $\begin{array}{l}\text {-Tsiqah } \\
\text {-Tsiqah }\end{array}$ & $\begin{array}{l}\text { Tabi 'in } \\
\text { alangan } \\
\text { pertengahan }\end{array}$ \\
\hline 3 & $\begin{array}{l}\text { Abd ar- } \\
\text { Rahman } \\
\text { ibn Abu } \\
\text { al-Qasim } \\
\text { ibn } \\
\text { Muham } \\
\text { mad bin } \\
\text { Abi } \\
\text { Bakar } \\
\text { Ash- } \\
\text { Shidiq }\end{array}$ & $\begin{array}{l}750 \\
M\end{array}$ & $\begin{array}{l}806 \\
M / \\
126 \\
H\end{array}$ & $\begin{array}{l}\text { Madina } \\
\mathrm{h}\end{array}$ & $\begin{array}{l}\text { Abu } \\
\text { Muham } \\
\text { mad }\end{array}$ & $\begin{array}{l}\text {-Tsiqah } \\
\text {-Tsiqah } \\
\text {-Tsiqah } \\
\text { wara' }\end{array}$ & $\begin{array}{l}\text { Tabi in } \\
\text { (Tidak jumpa } \\
\text { sahabat) }\end{array}$ \\
\hline 4 & $\begin{array}{l}\text { Sufyan } \\
\text { bin } \\
\text { ‘Uyainah } \\
\text { bin Abi } \\
\text { Imran } \\
\text { Maimun }\end{array}$ & & $\begin{array}{l}198 \\
\mathrm{H}\end{array}$ & Kufah & $\begin{array}{l}\text { Abu } \\
\text { Muham } \\
\text { mad }\end{array}$ & $\begin{array}{l}\text {-Hafidz } \\
\text { mutqin } \\
\text {-Tsiqah } \\
\text { tsabat } \\
\text {-Ahadul } \\
\text { 'alam } \\
\text {-Tsiqat tsabat } \\
\text {-Hafidz } \\
\text { imam }\end{array}$ & $\begin{array}{l}\text { Tabi'ut } \\
\text { Tabi'in } \\
\text { kalangan } \\
\text { pertengahan }\end{array}$ \\
\hline 5 & $\begin{array}{l}\text { Ali bin } \\
\text { Abdullah }\end{array}$ & & $\begin{array}{l}234 \\
\mathrm{H}\end{array}$ & Basrah & $\begin{array}{l}\text { Abu al- } \\
\text { Hasan }\end{array}$ & $\begin{array}{l}\text {-Disebutkan } \\
\text { dalam at- } \\
\text { tsigah }\end{array}$ & $\begin{array}{l}\text { Tabi'ul Atba } \\
\text { kalangan tua }\end{array}$ \\
\hline
\end{tabular}


Jurnal Riset Agama, Volume 1, Nomor 1 (April 2021): 15-28

Annisaa Siti Zuadah/Hadis tentang Haid dan Pengaruh Alat Kontrasepsi

Pencegah Kehamilan terhadap Siklus Haid

\begin{tabular}{|l|l|l|l|l|l|l|l|l|}
\hline $\begin{array}{l}\text { bin Ja'far } \\
\text { bin Najih }\end{array}$ & & & $\begin{array}{l}\text {-Tsiqah } \\
\text { ma'mun } \\
\text { imam } \\
\text {-Tsiqah } \\
\text { tsabat imam }\end{array}$ & \\
\hline 6 & $\begin{array}{l}\text { Imam al- } \\
\text { Bukhari }\end{array}$ & $\begin{array}{l}810 \\
\mathrm{M}\end{array}$ & $\begin{array}{l}870 \\
\mathrm{M}\end{array}$ & $\begin{array}{l}\text { Bukhar } \\
\mathrm{a} \\
\text { (Khusa } \\
\text { ran) }\end{array}$ & $\begin{array}{l}\text { Abu } \\
\text { Abdillah }\end{array}$ & $\begin{array}{l}\text { Imam fi al- } \\
\text { Hadis }\end{array}$ & Mudawwin \\
\hline
\end{tabular}

Tabel 1. adalah daftar rawi dan sanad yang sedang diteliti. Rawi adalah periwayat hadis sedangkan sanad adalah keseluruhan rawi (rantai periwayat) dalam suatu hadis dengan sifat dan bentuk yang ada (Rahman, 2016). Tabel ini menggambarkan transmisi hadis, sejak periwayat pertama sampai periwayat terakhir. Periwayat pertama adalah kalangan sahabat sebagai pihak pertama dalam penyampaian hadis, sedangkan periwayat terakhir adalah ulama penghimpun hadis ke dalam suatu kitab (Soetari, 2005). Hadis shahih merupakan hadis yang diklasifikasikan berdasarkan kualitasnya, dengan cara penyeleksian yang ketat. Bertujuan untuk menyajikan sebuah kebenaran, yang tidak bisa diragukan lagi. Mulai dari sanad yang bersambung, periwayat yang dhabit, 'adil, terhindar dari illat dan syadz (Nadhiran, 2014). Menurut ilmu hadis, syarat hadis shahih adalah ketika rawi menerima komentar positif dari ulama. Jika terdapat komentar ulama yang memberikan penilaian negatif kepada salah satu periwayat di lajur sanad, maka hadis tersebut termasuk dhaif (Darmalaksana, 2017). Karena tidak ada penilaian negatif dari komentar ulama dan sanad hadis bersambung maka status hadis ini dikategorikan sahih.

Sebaran hadis ini berperan sebagai syahid dan mutabi . Syahid adalah hadis lain yang sejenis, sedangkan mutabi adalah sanad lain (Darmalaksana, 2020). Syahid jalur sanad hadis ini terdapat dua lokasi. Pertama, dalam Sunan Abu Dawud, No 1704, yakni 'Abd ar-Rahman ibn Abi Bakar as-Siddiq. Kedua, Sunan an-Nasa i, No 2713, yakni Jabir ibn `Abd Allah. Jalur sanad hadis ini juga memiliki delapan mutabi', yaitu: 1) Sahih Muslim, No. 2122, yakni Zukun Maulana 'A'isyah; 2) Sahih Muslim, No. 2357, yakni al-Qad ibn Yazid ibn Qais; 3) Sahih Muslim, No. 2019, yakni 'Urwah ibn az-Zabir; 4) Sahih Muslim, No. 2119, yakni `Umrah binti `Abd ar-Rahman; dan 5) Sahih Muslim, No. 2356, yakni `Abd Allah ar-Rahman ibn `Auf (Rahmatullah, Haid (Menstruasi) dalam Tinjauan Hadis, 2016). Adapun redaksi hadis di atas terdapat dalam Sahih al-Bukhari, Nomor 285, Kitab: al-Haid, Bab: Kaifa kana Yad 'u al-Haidi. Para periwayat hadis ini adalah imam al-Bukhari, Ali ibn 'Abd Allah Sufyan, Abd ar-Rahman ibn Abu alQasim, al-Qasim ibn Muhammad, dan 'Aisyah (Rahmatullah, Haid (Menstruasi) dalam Tinjauan Hadis, 2016). Apabila ditinjau dari aspek Jarh wa Ta'dil tidak ada ulama yang menilai negatif periwayat tersebut. 
Jurnal Riset Agama, Volume 1, Nomor 1 (April 2021): 15-28

Annisaa Siti Zuadah/Hadis tentang Haid dan Pengaruh Alat Kontrasepsi

Pencegah Kehamilan terhadap Siklus Haid

Sebaliknya, penilaian-penilaian beberapa ulama Jarh wa Ta'dil membuktikan mereka adalah para periwayat yang tsiqah. Adapun secara at-Tahammul wa al-Ada ' kebanyakan para periwayat menggunakan metode al-Sama', yakni dengan hadasana dan sami 'tu. Metode al-Sama 'merupakan tingkatan paling tinggi dalam penerimaan at-Tahammul wa al-Ada'. Dengan demikian, penyampaian dari satu periwayat ke periwayat yang lainnya dapat dipertanggungjawabkan (Rahmatullah, 2016).

Syarah hadis telah dilakukan oleh para ulama sejak zaman klasik dengan berbagai pendekatan (Darmalaksana, 2020). Demikian pula, para imam madzhab yang empat bersepakat bahwa "Haid adalah darah yang keluar dari kemaluan (depan) seorang wanita, dalam keadaan sehat. Darah haid keluar dengan sendirinya pada seorang (wanita) sesuai dengan usia yang telah ditentukan, walaupun hanya setetes. Warna darahnya adalah satu dari merah, keruh, hijau, kuning, maupun hitam. Haid dan wanita adalah dua hal yang tidak bisa dipisahkan. Setiap wanita dipastikan akan mengalaminya, karena darah haid merupakan sifat alamiah setiap wanita. Ketentuan ini sebagaimana digambarkan oleh Nabi Muhammad Saw, bahwa haid adalah sesuatu yang telah ditetapkan oleh Allah Swt untuk anak-anak wanita Adam (Widad, 2017).

\section{Pengaruh Alat Kontrasepsi Pencegah Kehamilan terhadap Siklus Haid}

Dunia medis mengenal penunda kehamilan dengan istilah kontrasepsi. Kontrasepsi berasal dari dua kata, yaitu "kontra" yang berarti mencegah dan "konsepsi" yang berarti pembuahan atau pertemuan. Sehingga, kontrasepsi dapat diartikan sebagai suatu cara untuk mencegah terjadinya kehamilan sebagai akibat pertemuan antara sel telur dengan sperma. Kontrasepsi dapat menggunakan berbagai macam cara, baik dengan menggunakan hormon, alat ataupun operasi. Tingkat efektivitas dari kontrasepsi tergantung dari usia, frekuensi melakukan hubungan seksual, dan yang paling utama apakah menggunakan kontrasepsi tersebut dengan benar.

Banyak metode kontrasepsi yang memberikan tingkat efektivitas hingga 99\% jika digunakan secara tepat, di antaranya kondom, suntik, implan, IUD dan IUS, dan Pil KB.

Kondom merupakan jenis kontrasepsi penghalang mekanik. Kondom mencegah kehamilan dan infeksi penyakit kelamin, dengan cara menghentikan sperma untuk masuk ke dalam vagina. Suntikan kontrasepsi diberikan setiap 3 (tiga) bulan sekali. Suntikan kontrasepsi mengandung hormon progestogen, yang menyerupai hormon progesterone yang dihasilkan (wanita) selama 2 (dua) minggu pada setiap awal siklus menstruasi. Hormon tersebut mencegah wanita untuk melepaskan sel telur, sehingga memberikan efek kontrasepsi. Implan atau susuk kontrasepsi merupakan alat kontrasepsi berbentuk batang dengan panjang $4 \mathrm{~cm}$, yang di dalamnya 
Jurnal Riset Agama, Volume 1, Nomor 1 (April 2021): 15-28

Annisaa Siti Zuadah/Hadis tentang Haid dan Pengaruh Alat Kontrasepsi

Pencegah Kehamilan terhadap Siklus Haid

terdapat hormon progestogen. Implan dimasukan ke dalam kulit di bagian lengan atas, sehingga hormon tersebut akan dilepaskan secara perlahan ke dalam tubuh. Efektivitas implan sebagai alat kontrasepsi, dapat berlaku selama 3 (tiga) tahun. IUD (Intra Uterine Device) adalah alat kontrasepsi (kecil) berbentuk huruf T, yang diletakan di dalam rahim untuk mencegah kehamilan. Efektivitas IUD sangat tinggi sekitar 99,2\% sampai 99,9\%, yang berlaku selama 12 tahun. Sedangkan IUS (Intra Urine System) adalah alat kontrasepsi melalui pelepasan hormon progestogen, yang efektif selama 5 tahun. Pil KB kontrasepsi dapat berupa kombinasi hormon (Estrogen dan Progestogen) atau salah satu dari keduanya. Pil ini bekerja dengan cara mencegah terjadinya (ovulasi) dan mencegah terjadinya penebalan dinding rahim. Apabila pil kontrasepsi ini digunakan secara tepat, maka angka kehamilan yang akan terjadi hanya 3 dari 1.000 wanita (Muttaqin K. ,2019).

Salah satu efek dari penggunaan alat kontrasepsi hormonal, pada akseptor KB adalah ketidakteraturan siklus menstruasi, lama menstruasi, serta kejadian spoting (insiden bercak darah). Terjadinya insiden bercak darah yang tidak teratur, dengan kadar sedikit atau pendarahan di luar siklus (haid) yang kadang-kadang berkepanjangan (Setiawan, 2019). Di dalam kajian fiqh sendiri, terdapat kategorisasi dalam ketentuan masa haid yaitu: 1) Masa minimal haid. Seorang wanita mengalami haid, menurut ulama Hanafiyah adalah 3 hari 3 malam. Menurut ulama Malikiyah cukup hanya setetes (du fah), walaupun keluar setengah hari atau satu hari. Sedangkan, menurut ulama Syafi iyah dan Hanabilah menetapkan bahwa masa haid minimal sehari semalam yaitu 24 jam; 2) Masa kebiasaan haid. Lazimnya, seorang wanita mengeluarkan darah haid selama 6 atau 7 hari; dan 3) Masa maksimum haid. Imam Hanafi, memberi batasan maksimal haid 10 hari 10 malam. Imam Malik tidak memberi batasan maksimal haid, karena setiap wanita mempunyai masa haid yang berbeda-beda. Hanya saja, menetapkan 15 hari bagi seorang wanita yang pertama kali mengeluarkan darah haid (mubtada'ah). Sedangkan menurut pandangan Imam Syafi i dan Imam Hambali, batasan maksimum lamanya haid adalah 15 hari. Batasan-batasan yang diberikan oleh para ulama fiqh tersebut, menggambarkan betapa besarnya perhatian ulama terhadap permasalahan yang berkaitan dengan hal-hal terkait kewanitaan, khususnya dalam masalah menstruasi dan problem-problem yang dihadapi perempuan ketika itu (Nuraniyah, Fikih Menstruasi: Menghapus Mitos-Mitos dalam Menstruasi Taboo, 2019). Kontrasepsi adalah upaya untuk mencegah terjadinya kehamilan. Upaya tersebut dapat bersifat sementara, dapat pula bersifat permanen. Kontrasepsi dapat diartikan sebagai tindakan yang dapat membantu pasangan suami istri untuk menghindari kehamilan yang tidak diinginkan, mendapatkan (waktu) kelahiran sesuai yang diinginkan, dan menentukan jumlah anak sesuai yang diinginkan (Haslan, 2020). Kontrasepsi adalah konsep menghentikan kehamilan, sedangkan alat 
Jurnal Riset Agama, Volume 1, Nomor 1 (April 2021): 15-28

Annisaa Siti Zuadah/Hadis tentang Haid dan Pengaruh Alat Kontrasepsi

Pencegah Kehamilan terhadap Siklus Haid

kontrasepsi adalah segala macam alat atau cara yang digunakan oleh satu pihak atau dua pihak pasangan suami istri untuk menghindari (konsepsi). Kejadian gangguan siklus menstruasi di Indonesia diperkirakan dialami oleh $70 \%$ wanita, di mana 50\% di antaranya disebabkan karena pemakaian alat kontrasepsi (Lesmana, 2012).

Dalam dunia medis, metode kontrasepsi yang biasanya menjadikan masa haid tidak teratur adalah metode kontrasepsi hormonal, baik berupa KB suntik hormonal tiga bulan, implan, dan IUS (Intra Urine System). Sedangkan KB suntik satu bulan dan KB pil biasanya tidak menjadikan haid tidak teratur; haid tetap teratur seperti biasa, kecuali terdapat kelainan. Kategori kelainan (istihadhah) adalah sebagai berikut: 1) Pendarahan Uterus Abnormal (PUA). Merupakan pendarahan di antara dua pendarahan haid. Pendarahan ini, bisa terjadi di dalam atau di luar siklus haid. Pendarahan Uterus Abnormal (PUA) terjadi karena adanya kerusakan di dalam jaringan pembuluh darah, yang disebabkan oleh kelainan, seperti infeksi, tumor, dan disfungsi suatu jaringan yang menyebabkan pendarahan; 2) Peluruhan Uterus Disfungsional (PUD). Merupakan pendarahan di luar atau di dalam siklus haid. Peluruhan Uterus Disfungsional (PUD) dapat disebabkan oleh kelainan sel dalam korpus luteum (bercak-bercak darah sebelum masa haid), pembuluh darah pecah dalam rahim, gangguan dalam mekanisme pembekuan darah, dan pendarahan teratur atau tidak teratur (penurunan kadar esterogen);3) Plasenta Previa. Merupakan plasenta yang letaknya tidak normal; terletak di bagian bawah rahim yang dapat menutupi sebagian atau seluruh jalan lahir. Plasenta previa bisa terjadi pada wanita hamil yang sudah sering melahirkan, memiliki riwayat operasi sesar atau aborsi pada kehamilan sebelumnya, dan memiliki tumor jinak pada rahim; dan 4) Blody Show. Merupakan darah segar yang bercampur dengan rembesan air ketuban dan lendir, yang disebabkan kontraksi saat akan melahirkan. Blody show berasal dari beberapa pembuluh darah yang pecah dalam rahim, karena adanya kontraksi pada dinding rahim. Ini merupakan tanda bahwa bayi dalam kandungan, sudah siap keluar (Muttaqin K. ,2019). Meski darah haid yang keluar lebih lama dari waktu biasanya 15 hari, tetapi darah tersebut masih dikategorikan darah haid. Lamanya masa haid antara satu wanita, dengan wanita yang lainnya adalah berbeda-beda. Perbedaan tersebut bisa saja dipengaruhi oleh faktor keturunan, lingkungan, kondisi tubuh, dan juga bisa dipengaruhi faktor perbedaan cuaca dan gaya hidup. Adapun darah yang keluar dari kemaluan (wanita), yang menggunakan kontrasepsi dan lebih dari 15 hari, maka masih dikategorikan haid. Hal tersebut adalah salah satu efek penggunaan alat kontrasepsi, yang menjadikan darah haid tidak teratur; bisa melebihi batas 15 hari (Setiawan, 2019).

\section{Kesimpulan}


Jurnal Riset Agama, Volume 1, Nomor 1 (April 2021): 15-28

Annisaa Siti Zuadah/Hadis tentang Haid dan Pengaruh Alat Kontrasepsi

Pencegah Kehamilan terhadap Siklus Haid

Haid adalah darah yang keluar dari ujung rahim seorang wanita dalam kondisi sehat dan tidak dalam keadaan melahirkan. Darah haid tergolong najis sehingga wanita muslim tidak diwajibakan melaksanakah ibadah ketika datang masa haid kecuali telah bersuci. Orang di masa Jahiliyah percaya mitos yang menganggap kotor wanita haid untuk dikucilkan hingga berlangsung diskriminasi terhadap kaum perempuan. Islam menghapus mitos tersebut melalui sabda Nabi "Sesungguhnya ini adalah urusan yang telah dituliskan (ditetapkan) oleh Allah Swt terhadap perempuan-perempuan keturunan Adam." Dengan kedatangan Islam maka mitos menjadi lebur meskipun di beberapa budaya terbelakang masih dijumpai mitos-mitos serupa yang memosisikan perempuan menjadi terkucil. Meskipun status hadis berkualitas dhaif, namun dunia medis dapat menjelaskan haid sebagai siklus alamiah bagi perempuan. Hanya saja siklus tersebut menjadi tidak teratur ketika dunia medis mengenalkan penunda kehamilan dengan istilah kontrasepsi. Metode kontrasepsi mengacaukan masa haid, sedangkan jumhur ulama bersepakat tentang masa haid selama 15 hari, namun berdasarkan penjelasan medis darah yang keluar dari ujung rahim seorang wanita dengan penggunaan alat kontrasepsi yang lebih dari 15 hari, maka masih dikategorikan haid. Penelitian ini diharapkan memiliki implikasi manfaat bagi pengembangan khazanah keilmuan Islam. Diakui penelitian ini memiliki keterbatasan dalam penjelasan haid dari dunia medis sehingga dibutuhkan penelitian lebih lanjut yang menggabungkan dunia Islam dan dunia medis dalam pembahasan seputar wanita haid.

\section{Daftar Pustaka}

Agustina, D. (2019). Menggunakan Obat Penunda Haid Bagi yang Melaksanakan Ibadah Haji Menurut Pendapat Imam Yusuf AlQardawi dan Syeikh Ibnu Utsaimin (Studi Kasus Kecamatan Tanjungbalai Kabupaten Asahan).

Ain, A. (2017). Studi Komparatif Penganut Agama Islam Masjid Pusdai dan Penganut Agama Hindu Pura Agung Wira Loka Natha. Digilib Uin Sgd, 1-107.

Azzam, U. (2012). La Tahzan untuk Wanita Haid. Jakarta: Qultum Media.

Darmalaksana, W. (2017). Kontroversi Hadis sebagai Sumber Hukum Islam. Wawasan: Jurnal Ilmiah Agama dan Sosial Budaya, 245-258.

Darmalaksana, W. (2020). Metode Penelitian Kualitatif Studi Pustaka dan Studi Lapangan. Pre-Print Digital Library UIN Sunan Gunung Djati Bandung.

Darmalaksana, W. (2020). Penelitian Metode Syarah Hadis Pendekatan Kontemporer: Sebuah Panduan Skipsi, Tesis dan Disertasi. Diroyah: Jurnal Ilmu Hadis, 58-68. 
Jurnal Riset Agama, Volume 1, Nomor 1 (April 2021): 15-28

Annisaa Siti Zuadah/Hadis tentang Haid dan Pengaruh Alat Kontrasepsi

Pencegah Kehamilan terhadap Siklus Haid

Haslan, H. (2020). Hubungan Penggunaan KB Implant dengan Berat Badan dan Siklus Haid Akseptor KB. Jurnal Ilmiah Kesehatan Sandi Husada, 3.

Isna, M. (2018). Kontekstualisasi Larangan Talak Wanita Haid. Musawa Jurnal Studi Gender dan Islam, 62-69.

Lesmana, V. d. (2012). Hubungan Penggunaan Alat Kontrasepsi KB Suntik dengan Gangguan Siklus Haid di Wilayah Kerja Puskesmas Rantau Tijang Kecamatan Pugung Kabupaten Tanggamus . Jurnal Dunia Kesmas, 93-98.

Misbah, M. (2016). Hadis Mukhtalif dan Pengaruhnya terhadap Hukum Fikih: Studi Kasus Haid dalam Kitab Bidayatul Mujtahid. Riwayah: Jurnal Studi Hadis , 102-113.

Muttaqin, K. (2019). Haid dalam perspektif Islam dan sains: Studi tentang haid tidak teratur bagi pengguna kontrasepsi. Islamuna: Jurnal Studi Islam, 169-187.

Nadhiran, H. (2014). Kritik Sanad Hadis: Telaah Metodologis. Jurnal Ilmu Agama: Mengkaji Doktrin, Pemikiran dan Fenomena Agama, 91-109.

Nafsiyah, N. (2015). Studi Kualitas Sanad Hadits Membaca Al-Quran bagi Wanita Junub, Haid dan Nifas Tanpa Menyentuh Mushaf. Repository Uin Suska, 1-59.

Ningtyas, A. (2020). Penciptaan Karya Seni Grafis Bertema Tabu Menstruasi. SAKALA: Jurnal Seni Rupa Murni, 115-128.

Nuraniyah, W. (2019). Fikih Menstruasi: Menghapus Mitos-Mitos dalam Menstrual Taboo. Cirebon: PT Rajawali Buana Pusaka.

Rahman, M. (2016). Kajian Matan dan Sanad Hadits dalam Metode Historis. Jurnal Ilmiah Al-Syirah.

Rahmatullah, L. (2016). Hadis (menstruasi) dalam tinjauan hadis. PALASTREN: Jurnal Studi Gender, 23-56.

Rochmah, L. (2016). Hadis Tentang Wanita Haid Masuk Masjid (Kajian Mukhtalif al-Hadis dalam Sunan Abu Dawud No. Indeks 232 dan 261).

Romdion, A. (2015). Pemahaman tentang thaharah haid, nifas dan istihadhah: Studi kasus ibu-ibu jamaah muslimah Yayasan Masjid Darussalam Tropodo Sidoarjo. Justicia Islamica: Jurnal Kajian Hukum dan Sosial.

Setiawan, W. d. (2019). Telaah Ulang Wacana Haid dan Istihadhah pada Akseptor Keluarga Berencana. Ijtihad: Jurnal Wacana Hukum Islam dan Kemanusiaan, 103-123.

Soetari, E. (2005). Ilmu Hadis: Kajian Riwayah dan Dirayah. Bandung: CV Mimbar Pustaka.

Suhendra, A. (2014). Nilai Kearifan Lokal dalam Hadis: Studi atas Hadis Perempuan Menstruasi. Musawa: Jurnal Studi Gender dan Islam, 99110. 
Jurnal Riset Agama, Volume 1, Nomor 1 (April 2021): 15-28

Annisaa Siti Zuadah/Hadis tentang Haid dan Pengaruh Alat Kontrasepsi

Pencegah Kehamilan terhadap Siklus Haid

Widad, S. (2017). Konsepsi saat Masa Menstruasi Berdasarkan Perspektif Fiqh dan Medis. Oksitosin: Jurnal Ilmiah Kebidanan, 14-28. 